\title{
Potential bio-activity of whey fermented extract as sanitizer of organic grown lettuce
}

\author{
M.I.S. Santos ${ }^{\text {a, b, c }}$, S.R. Martins ${ }^{\text {a, b }}{ }^{\text {, L. Pedroso }}{ }^{\text {c }}$, I. Sousa ${ }^{\text {b }}$, M.A.S.S. Ferreira ${ }^{\text {a, * }}$ \\ a Microbiology Laboratory, Centro de Botânica Aplicado à Agricultura, CBAA, DRAT, Instituto Superior de Agronomia, Universidade de Lisboa, \\ 1349-017 Lisbon, Portugal \\ ${ }^{\mathrm{b}}$ Eco-processing of Food and Feed, CEER, DCEB, Instituto Superior de Agronomia, Universidade de Lisboa, 1349-017 Lisbon, Portugal \\ ${ }^{\mathrm{c}}$ Faculty of Veterinary Medicine, Universidade Lusófona de Humanidades e Tecnologias, Campo Grande, 376, 1749-024 Lisbon, Portugal
}

\section{A R T I C L E I N F O}

\section{Article history:}

Received 19 May 2014

Received in revised form

16 September 2014

Accepted 24 September 2014

Available online 2 October 2014

\section{Keywords:}

Whey

Lactic acid

Lettuce

Hygiene

Sanitizers

\begin{abstract}
A B S T R A C T
Consumption of vegetables is increasing due to demand for healthy products in peoples' diets. To reduce microbial contamination and maintain freshness, industrial processes in Portugal rely on minimally processing of vegetables with hypochlorite as sanitizer. Formation of toxic chlorine derivatives has raised concern restrictions to its use and alternatives with whey permeate as a disinfection agent has been attempted. The aim of this work was to evaluate the bio potential of fermented cheese whey, for use on disinfection of minimally processed lettuce organically grown.

Assays were made with whey obtained from inoculated milk during cheese processing, fermented for $120 \mathrm{~h}$ at $37^{\circ} \mathrm{C}$, after which, among other carbohydrates, lactic acid was measured by HPLC, giving average yields of $18 \mathrm{~g} \mathrm{~L}^{-1}$

The sanitizing effect of whey, undiluted, 75 and 50\% solutions, was compared with 110 ppm sodium hypochlorite, after rinsing. Aerobic Microorganisms (AM), Psychrotrophic Microorganisms (PM) and Enterobacteriaceae (ENT), were used as indicators for hygiene quality. For a level of significance of $P<0.05$, the hygiene quality standards of lettuce samples, were better using $75 \%$ whey solution (AM 6.62 , PM $7.48 \mathrm{cfu} \mathrm{g}^{-1}$ ), than using sodium hypochlorite (AM 7.48, PM $8.15 \mathrm{cfu} \mathrm{g}^{-1}$ ), for the 7 days of shelf life studied. Evaluation of Enterobacteriaceae showed significant differences after 3 days, between water (ENT $4.98 \mathrm{cfu} \mathrm{g}^{-1}$ ) sodium hypochlorite (ENT $4.81 \mathrm{cfu} \mathrm{g}^{-1}$ ) and 75\% solution of whey (ENT $4.63 \mathrm{cfu}^{-1}$ ).

Considering the actual limitations imposed to chlorine sanitation, these results point a good alternative to the food industry, especially for organic fresh vegetables, which are chemical free brands.
\end{abstract}

๑) 2014 Elsevier Ltd. All rights reserved.

\section{Introduction}

The variety of minimally processed (MP) produce, available at retail markets, reflects the increasing demand of consumers for healthy products. They are a low fat and low energy food source of vitamins, minerals, fibre, and antioxidants. Scientific evidences suggested that its consumption helps prevent a range of diseases, which includes coronary heart disease, type II diabetes and several cancers. These facts led the World Health Organization (WHO), as well as many health authorities of several countries, to stimulate the consumption of vegetables and fruits in the order of $400 \mathrm{~g}$ per day (WHO, 2013).

\footnotetext{
* Corresponding author. Tel.: +351 213653415.

E-mail addresses: massferreira@isa.ulisboa.pt, massferreira@isa.utl.pt (M.A.S.S. Ferreira).
}

Consequently, the food industry has responded to this demand with creative product development, new production practices and innovative use of technology (Artés, Gómez, \& Artés-Hernandez, 2007).

MP produce may be defined as any vegetable or fruit in the fresh state that has been physically altered from its original form and then packed, but remains in a fresh state and ready to use (GómezLópez, Ragert, Debever \& Dvlieghere, 2008).

Once vegetables are raw products of agricultural origin, are expected to contain microorganisms, including pathogens and minimal processing may increase the likelihood of microbial growth due to: 1) increase surface exposure, 2) release tissue intracellular content, 3) no assurance of sterility, 4) metabolism stability of plant tissue and finally 5) atmosphere confine packaging (Nguyen-the \& Carlin, 2000).

Recent reports on levels of Aerobic Microorganisms (AM) and/or Psychrotrophic Microorganisms (PM) and Enterobacteriaceae (ENT) 
Table 1

Composition of whey after $120 \mathrm{~h}$ fermentation at $37^{\circ} \mathrm{C}$, evaluated by HPLC.

\begin{tabular}{lllll}
\hline$\left(\mathrm{g} \mathrm{L}^{-1}\right)$ & Whey 1 & Whey 2 & Whey 3 & Average $^{\mathrm{a}} \pm \mathrm{sd}$ \\
\hline Lactose & 3.05 & 2.37 & 3.04 & $2.82 \pm 0.39$ \\
Galactose & 2.15 & 3.28 & 3.03 & $2.82 \pm 0.59$ \\
Glucose & - & - & - & - \\
Lactic acid & 17.88 & 18.76 & 18.49 & $18.38 \pm 0.45$ \\
Acetic acid & 0.58 & 1.03 & 1.05 & $0.89 \pm 0.27$ \\
Ethanol & 7.31 & 7.79 & 7.29 & $7.46 \pm 0.28$ \\
\hline
\end{tabular}

a Dilutions of whey at 75 and $50 \%$ contain three quarters and a half the amount of all carbohydrates evaluated by HPLC. Average figures are presented with standard deviation.

give orders of $10^{4}-10^{8}$ and $10^{3}-10^{7} \mathrm{cfu} \mathrm{g}^{-1}$ respectively (Abadias, Usall, Anguera, Solsona, \& Viñas, 2008; Froder et al., 2007; Santos et al., 2012). Although it does not indicate faecal contamination it can compromise sensorial and nutritive quality (Santos et al., 2012).

Guidelines for ready to eat (RTE) fresh or MP fruits and vegetables, generally specify as steps: 1) washing to remove dirt, pesticide residues and microorganisms and 2) sanitizing, usually with sodium hypochlorite (Beuchat, 1998; Beuchat \& Ryu, 1997; Brackett, 1987). Concern on formation of toxic derivatives, trihalomethanes and chloramine, harmful to human health has risen restrictions to use (Martinez-Sanchez, Allende, Bennett, Ferreres, \& Gil, 2006; Sapers, 2003). Although an increasing number of alternative methods has emerged, no one has acquired widespread acceptance by the industry (Martin-Diana et al., 2006). Therefore, new trends in food safety and sanitation, advise the use of natural products and consequently, assays on new preservative methods, effective on microbial growth reduction along storage, are important targets (Santos et al., 2012).

Increasing attention has been given to studies on use of whey permeate (WP) as a disinfection agent in vegetables (Martin-Diana et al., 2006). A significant antimicrobial effect of whey solutions was observed and no adverse effects on the sensory characteristics on trout were reported (Nykänen, Lapveteläinen, Kallio, \& Salminen, 1998).

The aim of this work was to evaluate the bio potential of naturally fermented cheese whey, containing industrial lactic acid starter bacteria, for its use as an antimicrobial agent solution, on disinfection of minimally processed lettuce purchased to organic growers.

\section{Materials and methods}

\subsection{Characterization of whey}

\subsubsection{Samples}

Samples of whey obtained by manufacture of cheese from mixed ewe, goat and cow's milk inoculated with a bacterial starter mix (Danisco, Sassenage, France) of Lactococcus lactis subsp. lactis, Lactococcus lactis subsp. cremoris, Lactococcus lactis subsp. lactis biovar diacetylactis, Streptococcus thermophilus and Lactobacillus delbrueckii subsp. bulgaricus, were collected at four different times during the season and kept at $-18{ }^{\circ} \mathrm{C}$ for analyses and assays whenever necessary.

\subsubsection{Chemical analyses}

The amount of sugars and acids present at the beginning, during and at the end of the fermentation assays were quantified through Ionic exchange in a High Performance Liquid Chromatography (HPLC) System (Waters Corporation, Milford, MA, USA), equipped with a 515 HPLC Pump, Waters Corporation, Milford, MA and incorporated with a Refractive Index Detector (RID) (486 Waters Corporation, Milford, MA, USA).

Prior to injection, samples were centrifuged at $10.000 \mathrm{rpm}$ (Eppendorf 5414D, Hamburg, Germany) for $10 \mathrm{~min}$ and the supernatants were filtered through a Millipore membrane with a pore size of $0.2 \mu \mathrm{m}$. Samples were injected in a Schodex SC-1011 column (Waters Corporation, Milford, MA, USA) and separations were achieved at $50{ }^{\circ} \mathrm{C}$, using $5 \mathrm{mM}$ Sulphuric acid as mobile phase (isocratic elution), at a flow rate of $0.6 \mathrm{~mL} \mathrm{~min}{ }^{-1}$. Calibration curves were made with standard solutions (in $5 \mathrm{mM}$ sulphuric acid) of lactose (Sigma-Aldrich, Netherlands) $30 \mathrm{~g} \mathrm{~L}^{-1}$, glucose (Panreac, Barcelona, Spain) $10 \mathrm{~g} \mathrm{~L}^{-1}$, galactose (Sigma-Aldrich, Netherlands) $15 \mathrm{~g} \mathrm{~L}^{-1}$, lactic acid (Sigma-Aldrich, Netherlands) $30 \mathrm{~g} \mathrm{~L}^{-1}$, acetic acid (Panreac, Barcelona, Spain) $5 \mathrm{~g} \mathrm{~L}^{-1}$, and ethanol (Aga, Lisboa, Portugal) $5 \mathrm{~g} \mathrm{~L}^{-1}$. Peak Integration was performed using the HPLC software Empower Pro (Waters Corporation, Milford, MA, USA). The Portuguese Norm NP-471(1983) was used for chloride ions measurements.

\subsubsection{Bacteriological and mycological analyses}

Samples were evaluated for presence of Salmonella spp., Listeria monocytogenes and Escherichia coli using ISO 6579:2002, ISO 11290-1:1996, Amendment. 1: 2004 and ISO 16649-2:2001 standards respectively. For detection and enumeration of yeasts spreading of $0.1 \mathrm{~mL}$ samples were also made onto duplicate plates of Glucose Yeast Peptone Agar (GYP), containing 0.5\% (w/v) of yeast extract (Biokar Diagnostics, Beauvais, France), 0.5\% (w/v) of peptone (Biokar Diagnostics, Beauvais, France), $2 \%(\mathrm{w} / \mathrm{v})$ of glucose (Copam, Portugal) and 2\% (w/v) of agar (Dário Correia, Portugal) incubated at $25{ }^{\circ} \mathrm{C}$ for 10 days.

\subsection{Lettuce origin}

Lettuce (Lactuca sativa) was always purchased to the same organically grower, at a local market, the day before the assays and kept under refrigeration at $4{ }^{\circ} \mathrm{C}$ until use.

\subsection{Assays of whey fermentation}

Whey obtained from inoculated milk with the starters referred in 1.1, during cheese processing, was diluted to achieve the final concentration of lactose of $30 \mathrm{~g} \mathrm{~L}^{-1}$, divided into aliquots of $500 \mathrm{~mL}$, distributed into Erlenmeyer flasks and placed into an incubator at $37^{\circ} \mathrm{C}$. Along time, at regular intervals, $5 \mathrm{~mL}$ samples were taken for pH measurement (Lab 850, Schott AG, Mainz, Germany) and HPLC

Table 2

Effect of sanitation assays of lettuce on Aerobic Microorganisms at $30^{\circ} \mathrm{C}$.

\begin{tabular}{|c|c|c|c|c|c|}
\hline Day & $100 \%$ whey & $75 \%$ whey & $50 \%$ whey & Sodium hypochlorite & Water \\
\hline 0 & $6.67 \pm 0.19^{\mathrm{b} * \mathrm{~A} \dagger}$ & $6.67 \pm 0.19^{\mathrm{bA}}$ & $6.67 \pm 0.19^{\mathrm{bA}}$ & $6.67 \pm 0.19^{\mathrm{aA}}$ & $6.67 \pm 0.19^{\mathrm{bA}}$ \\
\hline 1 & $5.03 \pm 0.16^{\mathrm{aA}}$ & $5.16 \pm 0.21^{\mathrm{aAB}}$ & $5.34 \pm 0.15^{\mathrm{aB}}$ & $5.76 \pm 0.11^{\mathrm{bC}}$ & $6.72 \pm 0.23^{\mathrm{bD}}$ \\
\hline 3 & $5.37 \pm 0.18^{\mathrm{aA}}$ & $5.53 \pm 0.12^{\mathrm{aA}}$ & $5.75 \pm 0.47^{\mathrm{aAB}}$ & $6.14 \pm 0.34^{\mathrm{cB}}$ & $7.18 \pm 0.16^{\mathrm{aC}}$ \\
\hline 5 & $6.05 \pm 0.27^{\mathrm{cA}}$ & $6.17 \pm 0.24^{\mathrm{bA}}$ & $6.31 \pm 0.14^{\mathrm{bAB}}$ & $6.68 \pm 0.21^{\mathrm{aB}}$ & $7.17 \pm 0.32^{\mathrm{aC}}$ \\
\hline 7 & $6.49 \pm 0.28^{\mathrm{bA}}$ & $6.62 \pm 0.34^{\mathrm{CAB}}$ & $6.80 \pm 0.30^{\mathrm{cAB}}$ & $7.03 \pm 0.11^{\mathrm{dBC}}$ & $7.41 \pm 0.11^{\mathrm{aC}}$ \\
\hline
\end{tabular}

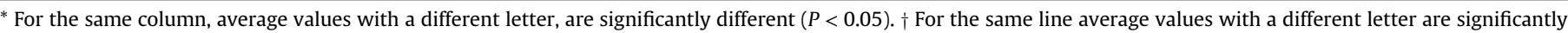
different $(P<0.05)$. Figures are $\log 10 \mathrm{cfu} \mathrm{g}^{-1}$ averages of duplicates of three independent trials presented with standard deviation. 
Table 3

Effect of sanitation assays of lettuce on Psychotropic Microorganisms.

\begin{tabular}{|c|c|c|c|c|c|}
\hline Day & $100 \%$ whey & $75 \%$ whey & $50 \%$ whey & Sodium hypochlorite & Water \\
\hline 0 & $4.67 \pm 0.37^{\mathrm{a}^{*} \mathrm{~A}_{\dagger}}$ & $4.67 \pm 0.37^{\mathrm{cA}}$ & $4.67 \pm 0.37^{\mathrm{cA}}$ & $4.67 \pm 0.37^{\mathrm{aA}}$ & $4.67 \pm 0.37^{\mathrm{bA}}$ \\
\hline 1 & $3.27 \pm 0.26^{\mathrm{bA}}$ & $3.44 \pm 0.35^{\mathrm{bA}}$ & $3.50 \pm 0.33^{\mathrm{bA}}$ & $3.63 \pm 0.20^{\mathrm{bA}}$ & $5.43 \pm 0.35^{\mathrm{cB}}$ \\
\hline 3 & $5.46 \pm 0.61^{\mathrm{cAB}}$ & $5.77 \pm 0.61^{\mathrm{aAB}}$ & $6.12 \pm 0.56^{\mathrm{dAB}}$ & $5.14 \pm 0.46^{\mathrm{aA}}$ & $7.15 \pm 0.46^{\mathrm{dC}}$ \\
\hline 5 & $6.37 \pm 0.39^{\mathrm{dA}}$ & $6.47 \pm 0.24^{\mathrm{aAB}}$ & $6.91 \pm 0.23^{\mathrm{aBC}}$ & $7.33 \pm 0.21^{\mathrm{cC}}$ & $7.98 \pm 0.35^{\mathrm{aD}}$ \\
\hline 7 & $7.15 \pm 0.27^{\mathrm{eA}}$ & $7.48 \pm 0.50^{\mathrm{dA}}$ & $7.48 \pm 0.50^{\mathrm{aA}}$ & $8.15 \pm 0.22^{\mathrm{dB}}$ & $8.48 \pm 0.22^{\mathrm{aB}}$ \\
\hline
\end{tabular}

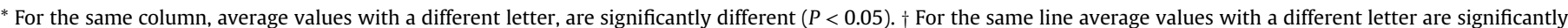
different $(P<0.05)$. Figures are $\log 10 \mathrm{cfu} \mathrm{g}^{-1}$ averages of duplicates of three independent trials presented with standard deviation.

determinations. Two equal consecutive $\mathrm{pH}$ measurements were considered as indication of the end of the fermentation process, which happened after $120 \mathrm{~h}$. At this time, fermented samples were divided into smaller portions and frozen at $-18{ }^{\circ} \mathrm{C}$ and kept until necessary. Assays were repeated in three independent trials.

\subsection{Preparation of sanitizer solutions}

Whey fermented extract solutions at 100, 75 and 50\% in water, were used for sanitation assays and compared with a chlorine solution of $110 \mathrm{ppm}$ made dissolving Amokina ${ }^{\circledR}$ (Angelini, Portugal) in sterile water, according to manufacturer instructions. All solutions were made the day before use and kept under refrigeration at $4{ }^{\circ} \mathrm{C}$.

\subsection{Sanitation procedure}

Two or three spoilt outer leaves were discarded in all samples and the unspoiled leaves of lettuce were taken and placed on a sanitized bench surface. Representative portions of all parts were taken, using a metal cutter with $6 \mathrm{~cm}$ diameter and soaked in sterilized distilled water for $10 \mathrm{~min}$ and kept in a cold room. After this time, samples were transferred into five plastic bags, weighted in $10 \mathrm{~g}$ portions and sanitized in $200 \mathrm{~mL}$ of the four sanitizing solution previously prepared. The fifth portion, marked as day 0 , was just soaked in sterile water and served as reference. All bags clamped and identified with the sanitizer solution under study, were stirred for $10 \mathrm{~min}$ at $4{ }^{\circ} \mathrm{C}$ using an incubator with orbital shaking (Panasonic MIR 154, Japan). At the end of this time, the five bags were opened and samples rinsed into sterile distilled water to remove sanitizers, placed into heat sealed bags and kept at $4{ }^{\circ} \mathrm{C}$ for
1, 3, 5 and 7 days, for microbiological determinations and evaluation of shelf life condition. Assays were repeated in three independent trials.

\subsection{Evaluation of the effect of sanitizers}

At 1, 3, 5 and 7 days intervals, bags were opened and samples transferred aseptically to sterile bags (Bagligth, PolySilk ${ }^{\circledR}, 400 \mathrm{~mL}$, Intercience, Saint Nom, France) diluted with $90 \mathrm{~mL}$ of sterile Ringer solution (Biokar Diagnostics, Beauvais, France), homogenized (Mastigator 400, IUL, Barcelona, Spain) for $90 \mathrm{~s}$ and decimal dilutions were prepared, according to standard ISO 6887-1:1999. The effect of sanitizers was determined by comparing reductions on AM at $30{ }^{\circ} \mathrm{C}$, (ISO 4833: 2003), PM, (ISO 17410: 2001), ENT, (ISO 215282: 2004). Lactic Acid Bacteria (LAB) were also enumerated by pour plating in MRS agar (Biokar Diagnostics, Beauvais, France) and incubated at $37^{\circ} \mathrm{C}$ for $24 \mathrm{~h}$, corresponding therefore to a MRS count.

All bacterial counts of colony forming units (cfu) were made using duplicate plates of three independent trials. Counts were statistically analysed using the software Statistica ${ }^{\mathrm{TM}}$ v10 from Statsoft, USA, to perform an ANOVA with a Tukey test with $\alpha=0.05$.

\section{Results and discussion}

Results from the microbiological analyses of whey, before fermentation assays, detected about $3.0 \times 10^{2}$ yeasts $\mathrm{cfu} \mathrm{mL}^{-1}$, but no pathogenic bacteria were found in our samples. The fermentation profile of products that was obtained by HCLP analyses is given in Table 1 and consists on metabolites composition.

Table 4

Effect of sanitation assays of lettuce on Lactic Acid Bacteria.

\begin{tabular}{|c|c|c|c|c|c|}
\hline Day & $100 \%$ whey & $75 \%$ whey & $50 \%$ whey & Sodium hypochlorite & Water \\
\hline 0 & $3.95 \pm 0.31^{\mathrm{c}^{*} \mathrm{~A} \dagger}$ & $3.95 \pm 0.31^{\mathrm{bA}}$ & $3.95 \pm 0.31^{\mathrm{aA}}$ & $3.95 \pm 0.31^{\mathrm{aA}}$ & $3.95 \pm 0.31^{\mathrm{aA}}$ \\
\hline 1 & $4.62 \pm 0.28^{\mathrm{aA}}$ & $4.48 \pm 0.30^{\mathrm{cA}}$ & $4.36 \pm 0.31^{\mathrm{abA}}$ & $3.50 \pm 0.26^{\mathrm{abB}}$ & $4.39 \pm 0.37^{\mathrm{abA}}$ \\
\hline 3 & $5.04 \pm 0.10^{\mathrm{abA}}$ & $4.91 \pm 0.19^{\mathrm{aA}}$ & $4.91 \pm 0.12^{\mathrm{bcAC}}$ & $4.15 \pm 0.23^{\mathrm{bB}}$ & $4.51 \pm 0.39^{\mathrm{abBC}}$ \\
\hline 5 & $5.21 \pm 0.13^{\mathrm{bA}}$ & $5.05 \pm 0.21^{\mathrm{aA}}$ & $5.21 \pm 0.34^{\mathrm{cdA}}$ & $4.99 \pm 0.33^{\mathrm{cA}}$ & $4.79 \pm 0.40^{\mathrm{bA}}$ \\
\hline 7 & $5.66 \pm 0.35^{\mathrm{dB}}$ & $5.53 \pm 0.22^{\mathrm{dAB}}$ & $5.53 \pm 0.29^{\mathrm{dAB}}$ & $5.12 \pm 0.28^{\mathrm{cA}}$ & $5.48 \pm 0.30^{\mathrm{CAB}}$ \\
\hline
\end{tabular}

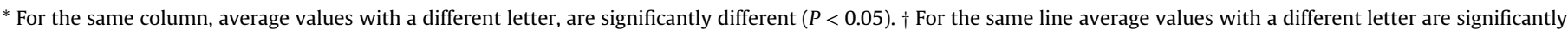
different $(P<0.05)$. Figures are $\log 10 \mathrm{cfu}^{-1}$ averages of duplicates of three independent trials presented with standard deviation.

Table 5

Effect of sanitation assays of lettuce on Enterobacteriaceae.

\begin{tabular}{|c|c|c|c|c|c|}
\hline Day & $100 \%$ whey & 75\% whey & $50 \%$ whey & Sodium hypochlorite & Water \\
\hline 0 & $5.23 \pm 0.14^{\mathrm{ab} * \mathrm{~A} \dagger}$ & $5.23 \pm 0.14^{\mathrm{abA}}$ & $5.23 \pm 0.14^{\mathrm{abA}}$ & $5.23 \pm 0.14^{\mathrm{abA}}$ & $5.23 \pm 0.14^{\mathrm{abA}}$ \\
\hline 1 & $3.76 \pm 0.17^{\mathrm{cA}}$ & $3.84 \pm 0.22^{\mathrm{cA}}$ & $3.91 \pm 0.20^{\mathrm{cA}}$ & $4.19 \pm 0.35^{\mathrm{cA}}$ & $4.82 \pm 0.52^{\mathrm{abB}}$ \\
\hline 3 & $4.49 \pm 0.22^{\mathrm{dA}}$ & $4.63 \pm 0.19^{\mathrm{dAB}}$ & $4.63 \pm 0.25^{\mathrm{dA}}$ & $4.81 \pm 0.30^{\mathrm{aAB}}$ & $4.98 \pm 0.31^{\mathrm{abBC}}$ \\
\hline 5 & $5.01 \pm 0.19^{\mathrm{aAB}}$ & $5.13 \pm 0.22^{\mathrm{aAB}}$ & $4.95 \pm 0.25^{\mathrm{aA}}$ & $5.06 \pm 0.34^{\mathrm{abAB}}$ & $5.54 \pm 0.50^{\mathrm{bcB}}$ \\
\hline 7 & $5.45 \pm 0.25^{\mathrm{bA}}$ & $5.52 \pm 0.31^{\mathrm{bA}}$ & $5.43 \pm 0.21^{\mathrm{bA}}$ & $5.47 \pm 0.46^{\mathrm{bA}}$ & $5.79 \pm 0.47^{\mathrm{cA}}$ \\
\hline
\end{tabular}

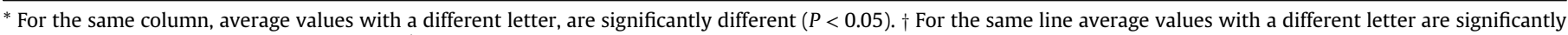
different $(P<0.05)$. Figures are $\log 10 \mathrm{cfu} \mathrm{g}^{-1}$ averages of duplicates of three independent trials presented with standard deviation. 
Lettuce that was used as food model in our work is under microbiological compliances, established by the European Regulation (EC) 2073: 2005 and its amendments, for RTE products, regarding the numbers of E. coli and Salmonella. Nevertheless, to evaluate the industrial hygienic process of sanitation, other microbiological indicators have been suggested as criterions. Determinations of AM at $30{ }^{\circ} \mathrm{C}$ have been used as good quality indicator for lettuce and other RTE products (Heard, 2002) with values detected ranging from 1.84 to $8.9 \mathrm{cfu} \mathrm{g}^{-1}$. Evaluating sanitation of our samples by the numbers of AM present after 7 days of shelf life assayed in this work (Table 2), cell counts of samples washed with $100 \%$ whey solution, is significantly lower $(P<0.005)$ than counts obtained with sodium hypochlorite as sanitizer. Because lettuce is stored under refrigeration, PM together with ENT, were considered as well, other good indicators for a sanitation process evaluation. The last group after all, consists of $10 \%$ of the total microbial load in RTE (Nguyen-the \& Carlin, 2000). Results of our lettuce samples shows in fact that PM are the greater bacterial group present and figures in Table 3 highlights that the hygienic capacity of sodium hypochlorite against this group, was not significantly different from water, by the end of the shelf life period studied. After $24 \mathrm{~h}$ there are already significant reductions on ENT counts, between lettuces washed with solutions of whey and water, and in the following days, although not significantly, they are smaller (Table 5). Nevertheless, no significant differences between all sanitizing solutions and water were found on the 7th day and sodium hypochlorite showed a reduced efficiency to control these Gram negative bacteria, which is in agreement with the reports observed in industry (Kim, Park, \& Rhee, 2014).

The sanitizing effect of whey in comparisons with sodium hypochlorite, over AM (Table 2), PM (Table 3) and ENT (Table 5) populations present, shows that along the 7 days of shelf life studied, the three solutions made out of whey, undiluted, 75 and $50 \%$ solutions, gave better or equivalent reductions on all $\log _{10}$ numbers of bacterial indicators used. The microbiological hygiene quality achieved using sodium hypochlorite, which is in used in most industrial premises in this country, were no better than the ones presented by samples sanitized by $75 \%$ whey solution. This fact may be due to the antibiotic potential of fermented whey, which beside lactic acid has a low $\mathrm{pH}$ and as well might have bacteriocins and other bioactive peptides (Nykänen et al., 1998). The solutions of whey used in this work, with an average $\mathrm{pH}$ of 3.19 (undiluted), have a content in lactic acid approximately of 1.8, 1.35 and $0.9 \%(\mathrm{w} / \mathrm{v}$ ) for concentrations of 100 (undiluted), 75 and 50\% respectively (Table 1 ). Work done previously in our laboratory, with organic acids on agar diffusion plates, demonstrated that water solutions of 1.5 and $3 \%(\mathrm{w} / \mathrm{v})$ of lactic acid, $\mathrm{pH} 3.34$ and 2.92 respectively, have a good antimicrobial effect against pathogenic Gram positive bacteria (Pintado, Ferreira, \& Sousa, 2009).

Regarding stability of lettuce, the presence of live LAB, from the starter mix used to ferment whey extracts, could increase these bacteria to levels of concern for its future purpose as sanitizer, because vegetables were considered unsatisfactory if more than 8 $\log _{10} \mathrm{cfu} \mathrm{g}^{-1}$ were present (HPA 2009). Evaluations presented on Table 4 showed that LAB (determined as MRS count), are naturally present on lettuce leaves, because cell counts on samples just washed in water, ranged from 3.95 to $5.48 \log _{10} \mathrm{cfu} \mathrm{g}^{-1}$ and no significant increase was caused along 7 days of shelf life, despite the fact of have been soaked in $200 \mathrm{~mL}$ of $75 \%$ whey solution.

No visible changes were detected on lettuce leaves appearance during the shelf life studied and we considered not relevant the evaluation of metabolite residues left after rinsing, because they are not toxic for human consumption. We considered the environment impact of waste water produced by this technology, less damaging than the use of chlorine solutions. Therefore, the use of solutions of fermented extracts of whey has proven a good bio potential to be used as sanitizer.

Considering the actual limitations imposed to chlorine use (Martinez-Sanchez et al., 2006) in the food industry, due to authorities restrictions and consumers health awareness, these results point a good alternative to chlorine sanitation, especially for organic fresh vegetables, which have a brand claim as chemicals free.

\section{Acknowledgements}

Authors would like to acknowledge Ricardo Chagas of Disease \& Stress Biology and Ana Carla Silva from the Microbiology Laboratory for technical assistance. We are very grateful to Sara Bernardes Silva, Technical Director of Indústria de Lacticínios, S.A., for providing the whey samples used in this work.

\section{References}

Abadias, M., Usall, J., Anguera, M., Solsona, C., \& Viñas, I. (2008). Microbiological quality of fresh, minimally-processed fruit and vegetables, and sprouts from retail establishments. International Journal of Food Microbiology, 123(1-2), $121-129$.

Artés, F., Gómez, P. A., \& Artés-Hernandez, F. (2007). Physical, physiological and microbial deterioration of minimally fresh processed fruits and vegetables. Food Science Technology International, 13(3), 177-188.

Beuchat, L. R. (1998). Surface decontamination of fruits and vegetables eaten raw. Geneva: Food Safety Issues, World Health Organization. WHO/FSF/FOS/98.2, (assessed on 22.02.14.) http://www.who.int/foodsafety/publications/fs_ management/surfac_decon/en/.

Beuchat, L. R., \& Ryu, J. H. (1997). Produce handling and processing practices. Emerging Infectious Diseases, 3(4), 458-465.

Brackett, R. E. (1987). Antimicrobial effect of chlorine on Listeria monocytogenes Journal of Food Protection, 50(12), 999-1003.

Commission Regulation (EC) $\mathrm{N}^{\circ} 2073$ (2005) of 15 November 2005 on microbiological criteria for foodstuffs. Official Journal, L338-1, Brussels.

Froder, H., Martins, C. G., Souza, K. L. O., Landgraf, M., Franco, B. D. G. M.. \& Destro, M. T. (2007). Minimally processed vegetables salads: Microbial quality evaluation. Journal of Food Protection, 70(5), 1277-1280.

Gómez-López, V., Ragert, P., Debevere, J., \& Dvlieghere, F. (2008). Decontamination methods to prolong the shelf-life of minimally processed vegetables, State-ofthe-art. Critical Reviews in Food Science and Nutrition, 48(6), 487-495.

Heard, G. (2002). Microbiology of fresh-cut produce. In O. Lamikanra (Ed.), Fresh-cut fruits and vegetables: Science, technology, and market (pp. 187-248). Boca Raton, EUA: CRC Press.

Heath Protection Agency. (2009). Guidelines for assessing the microbiology safety of ready-to-eat foods placed on the market. London: Heath Protection Agency.

ISO 11290-2. (1996). Microbiology of food and animal feeding stuffs - Horizontal method for the detection and enumeration of Listeria monocytogenes - Part I: Detection method. Amendment 1(2004). Modification of the isolation Media and the haemolysis test, and inclusion of precision data. Geneve, Suiça: International Organization for Standardization.

ISO 16649-2. (2001). Microbiology of food and animal feeding stuffs - Horizontal method for the enumeration of beta-glucuronidase-positive Escherichia coli - Part 2: Colony-count technique at $44{ }^{\circ} \mathrm{C}$ using 5-bromo-4-chloro-3-indolyl beta-Dglucuronidase. Geneve, Suiça: International Organization for Standardization.

ISO 17410. (2001). Microbiology of food and animal feeding stuffs - Horizontal method for the enumeration of psychotropic microorganisms. Geneve, Suiça: International Organization for Standardization.

ISO 21528-2. (2004). Microbiology of food and animal feeding stuffs - Horizontal methods for the detection and enumeration of Enterobacteriaceae - Part 2: Colonycount method. Geneve, Suiça: International Organization for Standardization.

ISO 4833. (2003). Microbiology of food and animal feeding stuffs - Horizontal method for the enumeration of microorganisms - Colony-count technique at $30^{\circ} \mathrm{C}$. Geneve, Suiça: International Organization for Standardization.

ISO 6579. (2002). Microbiology of food and animal feeding stuffs - Horizontal method for the detection of Salmonella spp. Geneve, Suiça: International Organization for Standardization.

ISO 6887-1. (1999). Microbiology of food and animal feeding stuffs - Preparation of test samples, initial suspension and decimal dilutions for microbiological examination Part 1: General rules for the preparation of the initial suspension and decimal dilutions. Geneve, Suiça: International Organization for Standardization.

Kim, N. H., Park, T. H., \& Rhee, M. S. (2014). Enhanced bacterial action of acidified sodium chlorite caused by the saturation of reactants. Journal of Applied Microbiology, 116(6), 1447-1457.

Martin-Diana, A., Rico, D., Frias, J., Mulcahy, J., Henehan, G., \& Barry-Ryan, C. (2006) Whey permeate as a bio-preservative for shelf life maintenance. Innovative Food Science and Emerging Technologies, 7(1-2), 112-123. 
Martinez-Sanchez, A., Allende, A., Bennett, R. N., Ferreres, F., \& Gil, M. I. (2006). Microbial, nutricional and sensory quality of rocket leaves as affected by different sanitizers. Postharvest Biology and Technology, 42(1), 86-97.

Nguyen-the, C., \& Carlin, F. (2000). Fresh and processed vegetables. In B. M. Lund, T. C. Baird-Parker, \& G. W. Gould (Eds.), The microbiological safety and quality of food (pp. 620-684). Gathersburg, USA: Aspen Publication.

NP 471. (1983). Determinação do teor de cloretos em leites. Caparica: Instituto Português da Qualidade.

Nykänen, A., Lapveteläinen, A., Kallio, H., \& Salminen, S. (1998). Effects of whey, whey-derived lactic acid and sodium lactate on the surface microbial counts of rainbow trout packed in vacuum pouches. LWT - Food Science and Technology, 31(4), 361-365.
Pintado, C. M. B. S., Ferreira, M. A. S. S., \& Sousa, I. (2009). Properties of wheyprotein based films containing organic acids and nisin to control Listeria monocytogenes. Journal of Food Protection, 72(9), 1891-1896.

Santos, M. I., Cavaco, A., Gouveia, J., Novais, M. R., Nogueira, P. J., Pedroso, L., et al. (2012). Evaluation of minimally processed salads commercialized in Portugal. Food Control, 23(1), 275-281.

Sapers, G. M. (2003). Washing and sanitizing raw materials for minimally processed fruits and vegetables. In J. S. Novak, G. M. Sapers, \& V. K. Juneja (Eds.), Microbial safety of minimally processed foods (pp. 221-253). Boca Raton, USA: CRC Press.

WHO. (2013). Global strategy on Diet, physical activity and health, promoting fruit and vegetable consumption around the world (assessed on 06.07.13.) http://www. who.int/dietphysicalactivity/fruit/en/index.html. 